\title{
Cytokine-Induced Killer Cells As Pharmacological Tools for Cancer Immunotherapy
}

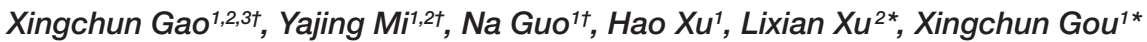 \\ and Weilin Jin ${ }^{1,3,4 *}$
}

'Shaanxi Key Laboratory of Ischemic Cardiovascular Disease, Institute of Basic Medical Sciences, Xi'an Medical University, Xi'an, China, ${ }^{2}$ State Key Laboratory of Military Stomatology, National Clinical Research Center for Oral Diseases, Shaanxi Engineering Research Center for Dental Materials and Advanced Manufacture, Department of Anesthesiology, School of Stomatology, The Fourth Military Medical University, Xi'an, China, ${ }^{3}$ Department of Instrument Science and Engineering, Institute of Nano Biomedicine and Engineering, Key Lab for Thin Film and Microfabrication Technology of Ministry of Education, School of Electronic Information and Electronic Engineering, Shanghai Jiao Tong University, Shanghai, China, ${ }^{4}$ National Centers for Translational Medicine, Shanghai Jiao Tong University, Shanghai, China

José Mordoh,

Fundación Instituto Leloir

Argentina

Reviewed by:

Estrella Mariel Levy,

Consejo Nacional de Investigaciones

Científicas y Técnicas (CONICET),

Argentina

Norberto Walter Zwirner,

Institute of Biology and Experimental

Medicine (IBYME-CONICET),

Argentina

*Correspondence:

Lixian Xu

xIx116@fmmu.edu.cn;

Xingchun Gou

gouxingchun@189.cn;

Weilin Jin

weilinjin@yahoo.com,

weilinjin@sjtu.edu.cn

tThese authors have contributed equally to this work.

Specialty section: This article was submitted to Cancer Immunity and Immunotherapy, a section of the journal

Frontiers in Immunology

Received: 24 April 2017 Accepted: 19 June 2017

Published: 06 July 2017

Citation:

Gao X, Mi Y, Guo N, Xu H, Xu L, Gou $X$ and Jin W (2017) CytokineInduced Killer Cells As

Pharmacological Tools for Cancer Immunotherapy. Front. Immunol. 8:774. doi: 10.3389/fimmu.2017.00774
Cytokine-induced killer $(\mathrm{CIK})$ cells are a heterogeneous population of effector $\mathrm{CD}^{+}{ }^{+} \mathrm{CD} 56^{+}$natural killer T cells, which can be easily expanded in vitro from peripheral blood mononuclear cells. CIK cells work as pharmacological tools for cancer immunotherapy as they exhibit MHC-unrestricted, safe, and effective antitumor activity. Much effort has been made to improve CIK cells cytotoxicity and treatments of ClK cells combined with other antitumor therapies are applied. This review summarizes some strategies, including the combination of CIK with additional cytokines, dendritic cells, check point inhibitors, antibodies, chemotherapeutic agents, nanomedicines, and engineering CIK cells with a chimeric antigen receptor. Furthermore, we briefly sum up the clinical trials on CIK cells and compare the effect of clinical CIK therapy with other immunotherapies. Finally, further research is needed to clarify the pharmacological mechanism of $\mathrm{CIK}$ and provide evidence to formulate uniform culturing criteria for $\mathrm{ClK}$ expansion.

Keywords: cytokine-induced killer cells, immunotherapy, pharmacological tools, cancer therapy, clinical trials

\section{INTRODUCTION}

Cancer is among the top killer diseases and has emerged as a major public health problem around the world, and it will still be the main cause of the morbidity and mortality during the next few decades (1). Bray et al. estimated that the incidence of all cancer cases would up to 22.2 million in 2030 (2). In order to cure cancer, researchers have tried many antitumor strategies, but the recurrence and mortality rate of cancer are still high. Adoptive immunotherapy, as an adjuvant or alternative treatment, holds great promise in treating various malignant tumors. Cytokine-induced killer (CIK) cells are considered to be an ideal candidate cell type for cancer immunotherapy. A lot of basic researches and clinical studies show the safety and feasibility of CIK therapy in treating malignant tumors. Combination of CIK with either immunological or genetic engineering approaches have been made to improve the effects of CIK and all the key events in the history of CIK immunotherapy are shown in Figure 1 (3-16). In this review, the research progress and clinical application of CIK are summarized. 


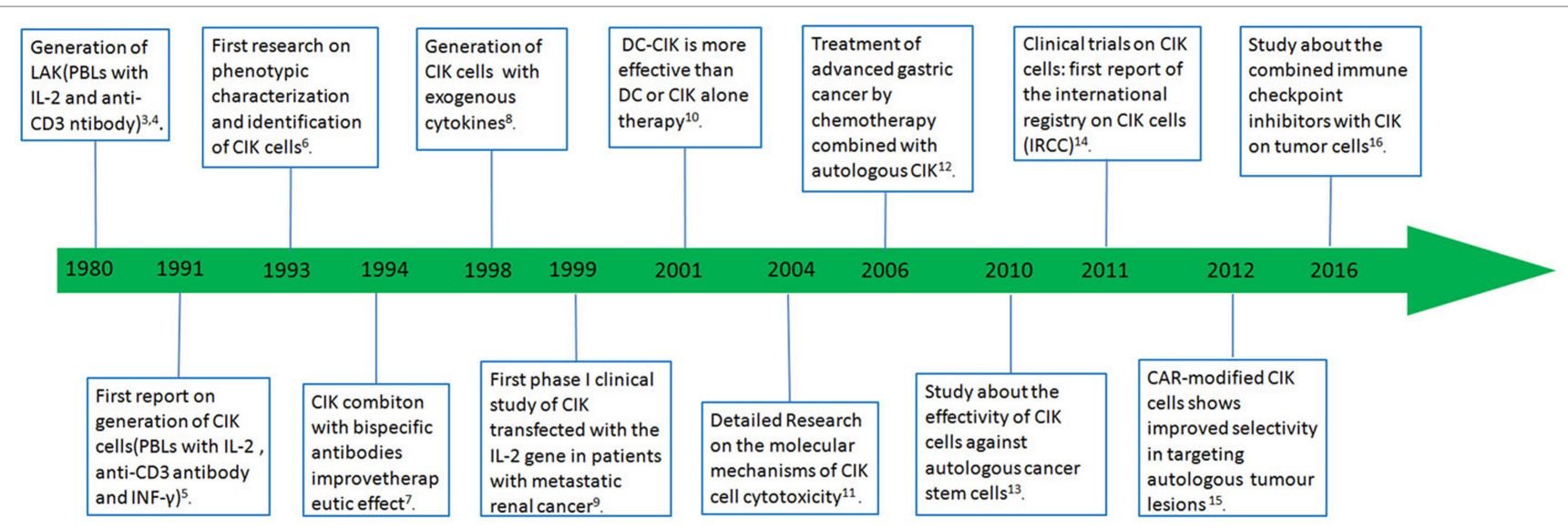

FIGURE 1 | Selected highlights in the development of immunotherapy.

\section{WHAT IS CIK?}

Cytokine-induced killer cells were first discovered in 1991 (5) and are a heterogeneous population of $\mathrm{CD}^{+} \mathrm{T}$ cells, which were generated from human peripheral blood lymphocytes (PBLs) and simply expanded ex vivo via incubation with an anti-CD3 antibody, interferon- $\gamma$ (IFN- $\gamma$ ), and interleukin (IL)-2. They can kill tumor cells mediated by FasL and perforin (17). According to the presence of cell surface molecule CD56, CIK cells are also divided into two main subsets: $\mathrm{CD}^{+} \mathrm{CD} 56^{+} \mathrm{T}$ cells and $\mathrm{CD}^{+}{ }^{+} \mathrm{CD} 56^{-} \mathrm{T}$ cells (18). $\mathrm{CD} 3^{+} \mathrm{CD} 56^{+} \mathrm{T}$ cells, which are also called the natural killer $\mathrm{T}$ cells, are considered to be the major effector cells of CIK. So, CIK cells can lyse cancer cells in a MHCunrestricted manner through activating NK cell receptors such as DNAX accessory molecule-1, NKp46, NKG2D, and NKp30 $(11,19,20)$. In addition to the direct killing effect of CIK on cancer cells, they can also regulate the immune function by secreting various cytokines. A lot of studies have indicated that after stimulation by tumor cells, the levels of pro-inflammatory cytokines such as tumor necrosis factor (TNF)- $\alpha$, IFN- $\gamma$, and IL-2 secreted by CIK cells are significantly upregulated (21), and these cytokines further enhance systemic antitumor activity and induce a Th1 immune response.

\section{EX VIVO EXPANSION AND ALLOREACTIVITY OF CIK CELLS}

Obtaining a sufficient number of antitumor immune cells is a critical step in the successful application of CIK cell immunotherapy (22). Fortunately, CIK cells can be easily expanded in vitro from peripheral blood mononuclear cells (PBMC), and some reports also showed that they could be also generated from umbilical cord blood precursors or bone marrow $(23,24)$. The general culture protocol for the ex vivo expansion of CIK cells requires 3-4 weeks with the addition of IFN- $\gamma$, anti-CD3 antibody, and IL-2. And the detail steps are as follows: on day 0 , the PBMC are separated by density-gradient centrifugation from the whole blood $(24,25)$ and treated with IFN- $\gamma$ to activate macrophages, which further provide cytokine-mediated (IL-12) and contact-dependent (CD58/LFA-3) signals to promote the cytotoxic power of CIK cells (26-28). On day 1 , anti-CD3 antibody and IL-2 are added to the medium. Anti-CD3 will provide mitogenic signals for $\mathrm{T}$ cells which are then sustained by the continuous presence of IL-2 $(29,30)$. Fresh medium with IL-2 is added every 2 days. After 3-4 weeks of culture, the generated CIK cells are subsequently infused back into patients (Figure 2). The amount of injected CIK cells varied in different studies, so did the cell expansion rates. In fact, the average final expansion rates were usually in a range of 100 -fold, but individual expansion rate was described to be variable from few to more than 1,000 -fold $(5,25,31,32)$. It is well known that the more the CIK cells are injected and expanded, the better they response. Hontscha et al. showed that the total number of injected CIK cells ranged from $21.9 \times 10^{7}$ to $5.2 \times 10^{10}(14)$, Li et al. found the total number of CIK cells ranged from $6 \times 10^{6}$ to $1.5 \times 10^{10}$ in Chinese clinical trials (33). Until now, the least injected number of CIK cells was reported to be $6 \times 10^{6}$ to obtain an objective response. Cohen et al. considered that tumor-infiltrating lymphocytes (TILs) must be expanded to $10^{10}$ for a successful treatment (34). Therefore, $\sim 10^{10} \mathrm{CIK}$ cells might be a good choice and many studies used more than $1 \times 10^{10}$ cells to transfuse into the patients. As mentioned above, the reason why CIK expansion rate varies greatly is unclear. But there are still some additional strategies under investigation to further improve the expansion of CIK cells (22), which include adding new cytokines to the culture medium, such as IL-1, IL-7, IL-15, or thymoglobulin $(8,35,36)$.

Cytokine-induced killer immunotherapy, a personalized therapy that uses patients' own PBMC to expand antitumor CIK cells which are then reinjected into patients themselves, rarely causes autoimmune response. But sometimes, it is very difficult to obtain a sufficient number of CIK cells due to the poor health situation of patients, such as elderly people and patients with immunodeficiency diseases (37). To solve this problem, getting CIK cells from donor PBMC seems to be an alternative option. Studies showed that CIK cells exhibited a decreased alloreactivity across HLA barriers that could further reduce the risk of graft-versus-host disease (GVHD). Many phase I clinical studies 


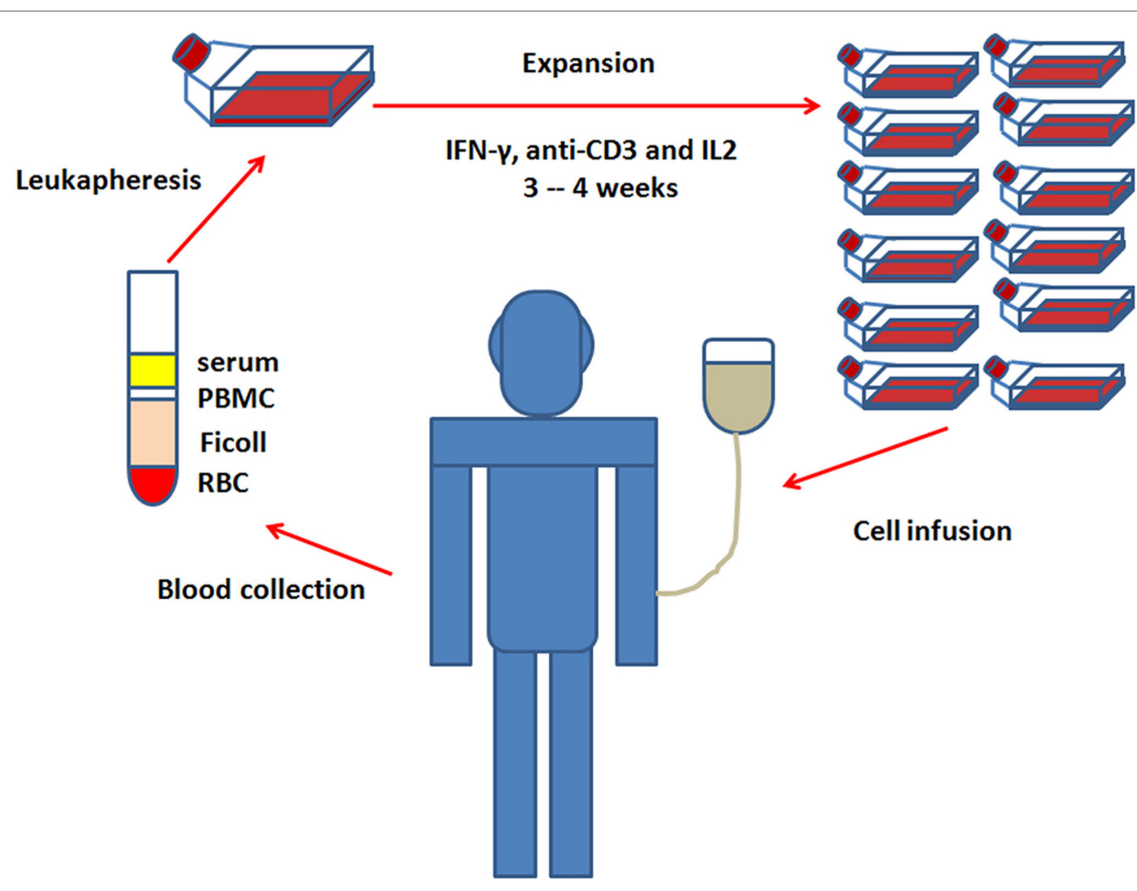

FIGURE 2 | Ex vivo expansion of cytokine-induced killer cells and infusion.

proved that infusion of the allogeneic CIK cells in patients relapsing after allogeneic hematopoietic cell transplant would reduce the incidence of GVHD events (38-40). Another solution to obtain sufficient CIK cells is collecting from the cord blood. Mature protocols have already been made for generation of cord blood-derived CIK (CB-CIK) cells (41). The CB-CIK cells displayed relatively lower expression of HLA, indicating a weaker immunogenicity and lower risk of GVHD (42). Many clinical trials proved that $\mathrm{CB}-\mathrm{CIK}$ cells were effective and safe to patients with malignancies $(43,44)$. All these suggest that CIK is a safe immune therapy with lower risk of GVHD.

\section{IMPROVED CIK THERAPY}

In the last decade, CIK cells have begun to be used in clinical care with good prospects for treatment success, and a great deal of research has been done to improve their cytotoxicity and safety. Here, we have summarized the current improved CIK therapies (Figure 3) $(45,46)$.

\section{CIK Combined with Additional Cytokines}

Cytokine-induced killer cells are a heterogeneous cell population that can be expanded ex vivo from PBMC with the addition of IFN- $\gamma$, anti-CD3 antibody, and IL-2. In fact, many additional cytokines have been made to improve CIK antitumor activity. These cytokines can improve cell proliferation and cytotoxicity partly by suppressing the generation of regulatory $\mathrm{T}$ (Treg) cells that are known to inhibit antitumor immunity.

$\mathrm{Lu}$ et al. reported a new protocol for expansion of highly efficient cytotoxic CIK cells by culturing PBLs with addition of IL- $1 \alpha$ (23). Another research showed that addition of IL-6 could significantly decrease the percentage of Treg cells and simultaneously increase the proliferation ability and cytotoxicity of the CIK cells against hepatocellular carcinoma (HCC) in vitro (47). By transfecting IL-7 gene expression vector into CIK cells, Finke et al. demonstrated an improved proliferation rate and enhanced antitumor cytotoxicity of CIK cells (48). Further study showed an upregulation of LFA-1 (CD11a/CD18) and CD28 in CIK cells with the addition of exogenous IL-7, which were essential for cytotoxic activity of CIK and played an important costimulatory role in T cell activation, respectively (49).

As an immune stimulatory cytokine, IL-12 has the strongest antitumor activity that can induce a Thl type of response and active NK and cytotoxic T lymphocyte (CTL) cells (50). CIK cells, generated with exogenous IL-12 instead of IL-2, showed similar cytotoxicity (8). However, due to its high toxicity, a lower dose of IL-12 should be used in combination with CIK in clinical application (50). Many studies demonstrated that CIK cells stimulated with IL-15 displayed improved proliferation capacity and cell cytotoxicity against hematologic and solid malignancies $(36,51-55)$. And a possible mechanism for its function might be the regulation of Treg cells and the expression of toll-like receptor 4, Wnt 4, PDGFD, and IL-35 (51, 56, 57). Application of IL-21 did not increase the proliferation rate of CIK cells $(58,59)$, but the cell cytotoxicity was significantly enhanced by increasing expression of IFN- $\gamma$, TNF- $\alpha$, perforin, and granzyme $\mathrm{B}$.

\section{Dendritic Cell (DC)-CIK}

Dendritic cells are professional antigen-presenting cells (APCs) that can capture and process tumor-associated antigens (TAAs) (60). Given their particular ability to stimulate both adaptive 


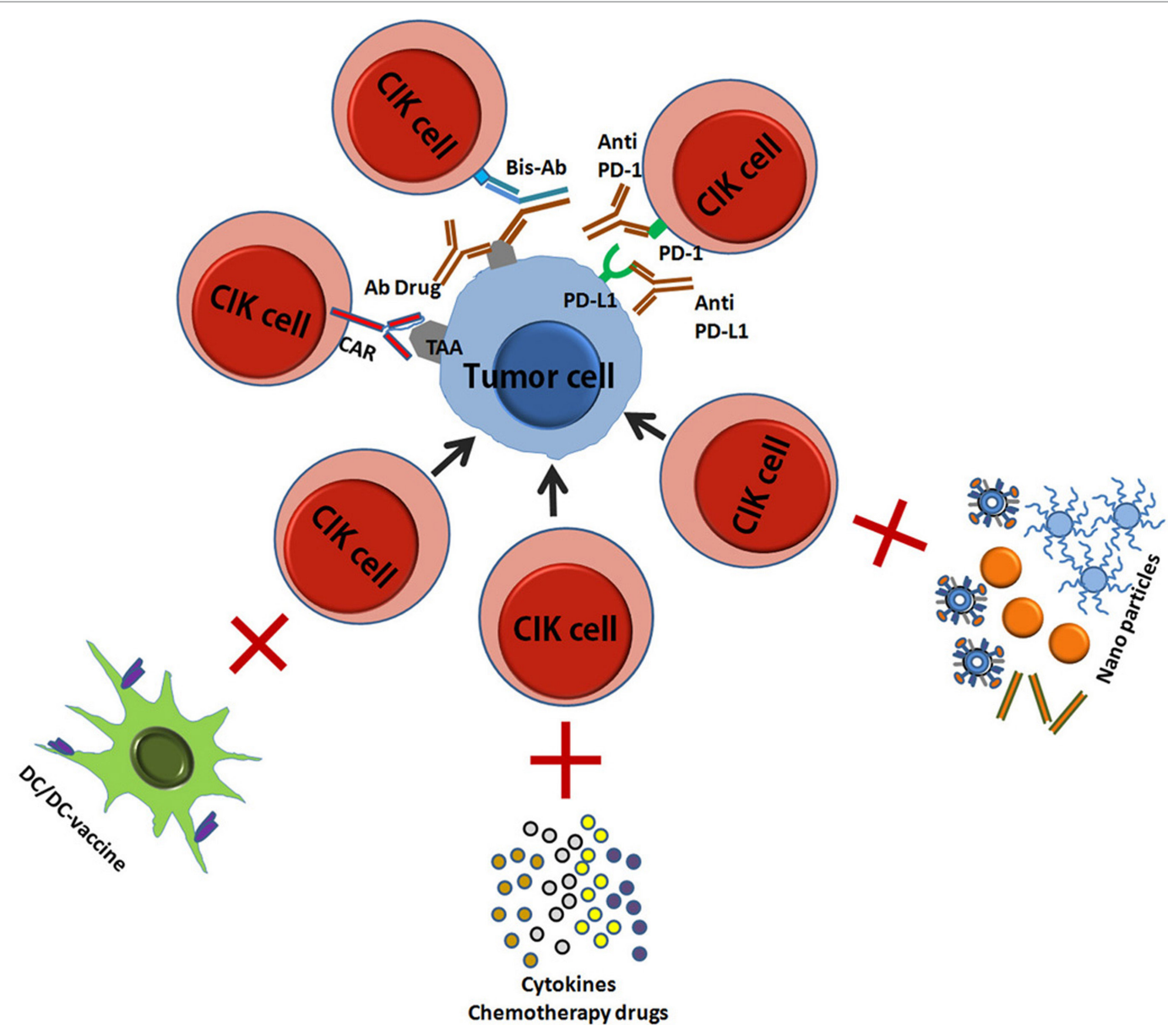

FIGURE 3 | A schematic picture showed the improved CIK therapy. CIK, cytokine-induced killer; TA, tumor antigen; CAR, chimeric antigen receptor; Bis-Ab, bispecific antibody; Ab, antibody; DC, dendritic cells.

and innate antitumor immune responses, DCs have been used as a powerful pharmacological tool for cancer immunotherapy (61). Many researches showed that DCs could promote NK celldependent antitumor effects through a cell-to-cell contact $(62,63)$. In recent years, studies have focused on the combinational treatment of DCs and CIK cells and proved a relative more safe and effective therapeutic effect on advanced solid carcinoma, which provide a new and efficacious immunity therapeutic strategy for cancer treatment. Cao et al. showed that coculture of CIK cells with DCs in vitro could improve the proliferation rate and antitumor activity of CIK cells (64). Further studies showed that the cellular interactions between CIK cells and DCs led to changes in the surface molecule expression of both populations and a significant increase of IL-12 secretion, and finally resulted in a higher cytotoxic activity of CIK cells (10). Pan et al. reported that DCs decreased the concomitant expanded Tregs in CIK cells and enhanced the cytotoxicity of CIK cells against leukemia cells (65). As we all know, delivering TAAs to DCs as vaccines have been reported to be an effective strategy for the treatment of various advanced malignancies. The combination of DCs vaccination with CIK cells is considered to be more prospected, and studies showed a significantly stronger antitumor activity and fewer side effects $(17,66-69)$. Jung et al. showed that in an in vivo animal model, the CIK + DC vaccination therapy was more effective than CIK or DC vaccination alone therapy for the treatment of hepatocarcinoma tumor cells (70). More recently, Lin et al. reported that DC-CIK therapy could improve survival by reducing the risk of disease progression in stage IV breast cancer patients (71).

\section{CIK Combined with Immune Checkpoint Inhibitors}

Immune checkpoints are molecules that can either turn up or turn down signals in immune system. When CTLs recognize and trigger tumor cell death by inducing apoptosis, various checkpoint pathways between APCs/tumor cells and T cells are activated to provide signals for $\mathrm{T}$ cell activation $(72,73)$. There are at least two signaling pathways regulating the activation or inhibition of the CTLs: the primary signal is the binding occurred between peptide-MHC which is presented by APCs and T cell receptors. The secondary signal is the costimulatory/coinhibitory signal that regulates $\mathrm{T}$ cell activation $(74,75)$. The CD28, OX40, CD58, CD40L, CD80, CD86, and CD137 are stimulators that can promote immune activation, whereas programmed death 1 (PD-1), cytotoxic lymphocyte-associated antigen 4 (CTLA-4), lymphocyte 
activation gene 3 (LAG-3), T cell immunoreceptor with Ig and ITIM domains, and T-cell immunoglobulin and mucin-domain containing-3 (TIM-3) are inhibitors that suppress immune activation. CTLA-4 and PD-1 involved in the T-cell immune evasion in many malignancies, thus they are always designed as targets for cancer immune therapies $(16,76)$. It has been demonstrated that the blockade of inhibitory receptors such as PD-1, KIR, TIM-3, and LAG- 3 but not CTLA- 4 on CIK cells can significantly increase their antitumor potency against hematological malignancies. However, the combination of inhibitors against two receptors showed no increased cytotoxicity compared to that of one alone (77). Dai et al. reported that the blockade of PD-L1/PD-1 augmented CIK cytotoxicity against gastric and colorectal cancer cells. Additionally, combined therapy of CIK with checkpoint inhibitors (PD-L1/PD-1 blockade) could inhibit tumor growth and prolong the survival in the murine model of gastric cancer compared to untreated mice (16). All these suggest that combination of CIK cells with checkpoint inhibitors will be a novel immunotherapy for cancer treatment.

\section{CIK Combined with Antibodies}

Immunotherapy of tumors with specific antibodies has been established as one of the most successful therapeutic strategies in the last 20 years. The mechanisms of antibody-based tumor cell killing are as follows: (1) antibody can directly bind to the cell surface receptor, deliver drug or toxin to target tumor cells, induce cell apoptosis, and reduce proliferation; (2) antibody can kill tumor cells by immune-mediated killing mechanisms such as activating complement, antibody-dependent cellular cytotoxicity, and regulating $\mathrm{T}$ cell function; (3) antibody can regulate tumor angiogenesis by vasculature receptor antagonism or ligand trapping $(78,79)$. Many studies showed that CIK cells combined with antibody could improve their cytolytic activity. Pievani et al. reported that addition of anti-CD20 mAb rituximab or GA101 could significantly enhance cytotoxicity of CIK cells to B-cell lymphoma in vitro (20). Deng et al. further proved that the enhanced CIK cytotoxicity induced by anti-CD20 mAb was partly related to the increased expression of components of the MAPK/ERK and STAT signaling pathways (80). Esser et al. reported that the combinational treatment of CIK cells with anti-CD30 mAb Brentuximab Vedotin (SGN-35) achieved better efficacy in CD30+ lymphoma, and SGN-35 did not affect the function of CIK cells (81). Besides, bispecific antibodies (BsAbs) that have two different antigen-binding sites could improve adoptive immunotherapy effect by cross-linking CIK cells with malignant tumor cells (82). BsAb CD19 × CD5 (HD37 × T5.16) has been reported to increase the cytolytic activity of CIK cells against B-lymphoma cells (83). BsAbs against cancer antigen-125 and Her2 significantly enhanced the cytotoxicity of CIK cells in primary ovarian cancer in both in vitro and in vivo models (84). BsAb EGFR/CD3 could improve the cytotoxic activity of CIK cells toward gastric cancer cells (85). When combined with anti-CD3/anti-CD133 BsAb, CIK cells showed significantly stronger cytotoxicity to $\mathrm{CD} 133^{\text {high }}$ pancreatic and hepatic cancer cells than that of CIK, CD3-CIK, or BsAb alone (86). Recently, $\mathrm{Ma}$ et al. reported that CIK cells armed with BsAb CD3 $\times$ EGFR (EGFRBi-Ab) to target EGFR-positive glioblastoma significantly increased CIK cells cytotoxic activity in vitro and inhibited the growth of glioblastoma tumors in glioblastoma xenograft mice (87). All these data suggest a better in vitro and in vivo antitumor effect of CIK cells combined with antibodies, which will definitely provide a novel useful method for the CIK cells.

\section{CIK Combined with Chimeric Antigen Receptor (CAR)}

To promote target cell recognition and improve specific cytotoxicity of CIK, CIK cells are always engineered with a CAR that is targeted to specific antigen. CIK cells engineered with a CAR that was directly targeted against carcino-embryonic antigen (CEA) showed improved activation toward $\mathrm{CEA}^{+}$colon carcinoma cells, compared to that of $\mathrm{CEA}^{-}$cells (15). Oelsner et al. proved that CD19 CAR-engineered CIK cells could dramatically enhance their antileukemic activity (88). Remarkably, Marin et al. found that CIK cells combined with CD19-target CARs containing a costimulatory $\mathrm{CD} 28$ or $4-1 \mathrm{BB}$ domain together with $\mathrm{CD} 3 \zeta$ exhibited better antitumor effect than CARs based on DAP10 or CD3 $\zeta$ alone $(89,90)$. Likewise, Hombach et al. reported that CIK cells arming with CD28-CD3 $\zeta$ CAR showed stronger cytotoxicity; however, CIK cells arming with the third-generation CD28-CD3ל-OX40 CAR that provided a super costimulation signal exhibited less antitumor efficacy due to increased activation-induced cell death (91). All these data indicate that CIK cells modified by CAR have stronger tumor cell killing activity, and the appropriate design for CAR is crucial for the successful application of CAR-mediated CIK response.

\section{CIK Combined with Chemotherapy}

Many studies have shown that CIK/DC-CIK combined with different chemotherapy regimens for cancer treatment exhibited better efficacy than chemotherapy alone. Wu et al. showed that CIK cells plus chemotherapy (docetaxel and cisplatin) could significantly prolong the progression-free survival (PFS) and overall survival (OS) in advanced non-small-cell lung cancer (NSCLC) patients (92). Niu et al. proved that CB-CIK cells combined with second-line chemotherapy drug (dexamethasone) could improve PFS and OS in patients with advanced solid malignancies after first-line chemotherapy failure (44). As we all know, chemoresistance is a major problem to be solved in the treatment of cancers. Interestingly, many studies showed that the combination of CIK with chemotherapy could overcome chemotherapy resistance by activating the immune system $(93,94)$. Zheng and Han analyzed the efficiency and safety of chemotherapy combined DC with CIK cells in the treatment of NSCLC using meta-analysis. They found that chemotherapy combined with DC-CIK immunotherapy was superior in 1-year OS, disease control rate (DCR), and disease-free survival (DFS). Meanwhile, no more adverse events (AEs) appeared. However, there was no obvious improvement in objective response rate (ORR), partial response, 2-year PFS, and OS. All these suggested the combination therapy was modest in efficacy and safer for advanced NSCLC patients $(95,96)$. Similar results, with significantly prolonged $1-5$ year OS, DFS, and improved DFS, ORR, and DCR with the infusion of CIK/ DC-CIK combined with chemotherapy was reported by $\mathrm{Mu}$ 
et al. in patients with gastric cancer. Moreover, the levels of IFN- $\gamma$ and IL-12, except IL-2, significantly increased after CIK/ DC-CIK therapy, proving that the immune function of gastric cancer patients also significantly improved (97). Another metaanalysis proved that DC-CIK combined with chemotherapy could prolong 1-year OS, 2-year OS, and 3-year OS on colon cancer (98). All these data indicate an antitumor effect of CIK and chemotherapy in comparison with the use of chemodrugs or CIK cells alone.

\section{CIK Combined with Nanomedicine}

With the rapid development of nanotechnology and nanomedicine, nanomaterials have been applied in various fields, especially in human health care. In recent years, nanotechnology has brought many new methods for cancer treatment (99-103). Nanometer-sized particles $(1-100 \mathrm{~nm})$ are in the same range of dimension as biomacromolecules including antibodies and membrane receptors (104). Their inherent physical/chemical properties or being loaded with different imaging/therapeutic agents in their surface, all of which make nanoparticles become a powerful tool for diagnosis, imaging, and therapy (105-107). Importantly, nanomaterials with low toxicity can be used as vaccine carrier/adjuvant to improve the immunogenicity of antigens by enhancing their cellular uptake, preventing enzyme degradation, and regulating the immune cells function $(108,109)$. Many researchers explored the potential applications of nanomaterials in monitoring the trafficking of DCs and enhancing the efficacy of DC-based cancer vaccines, such as quantum dots (110), magnetic nanoparticles (111-114), and upconversion nanoparticles (115). Furthermore, it has been reported that nanoparticles could also work as cancer vaccines (116), and these cancer nanovaccines could be envisioned as nanocarriers codelivering antigens and adjuvants (117-119). As we discussed, the efficacy of DC-CIK is better than DC or CIK alone, so we propose that the combination of CIK/DC-CIK cells with nanomaterials may have a great potential in cancer immunotherapy.

\section{CLINICAL TRIALS ON CIK CELLS}

At present, CIK as a pharmacological tool for cancer therapy has been tested in clinical trials of various tumors. 90 registered clinical trials have been found on the website ClinicalTrials. gov (http://www.clinicaltrials.gov) (Table 1) by searching the keywords: cytokine-induced killer cells or CIK. One trial is working on psoriasis (Table 1). The majority of these are concentrated in China (58 studies), followed by 6 studies in U.S., 3 studies in Singapore, and 3 studies in Korea. Besides, two trials (NCT01533727, NCT02539017) have been withdrawn, 1 trial terminated (NCT01871480), 22 trials have been completed. Below, we will summarize these clinical trials on CIK cells.

In a first Phase I study, Schmidt-Wolf et al. demonstrated the safety and initial activity of CIK in therapeutic trials (9). In addition, CIK cells could be successfully expanded from patients treated with or without chemotherapy (120), so CIK cells were widely applied to treat various types of tumors including HCC, lung cancer, and gastrointestinal tumors (Table 1).
Lee et al. reported that patients who received CIK immunotherapy after curative treatment for HCC had a 14-month median recurrence-free survival (RFS) benefit (121). The OS and cancer-specific survival were longer in the immunotherapy group compared to the control group. The ratio of AEs was significantly higher in the immunotherapy group $(P=0.002)$, but there was not a significant difference in the proportion of patients with serious AEs between groups $(P=0.15)$ (NCT00699816). It is worth noting that previous studies about CIK therapy for HCC showed significant benefits in preventing recurrence, but no significant survival gains (122-124). The difference of these results may be due to several aspects, such as the different intensified schedule of CIK, different cancer clinical stage or the non-standard quality of CIK cells (commercialized CIK cell compared to uncommercialized CIK cells). Lee et al. proved that adjuvant immunotherapy with activated CIK cells could increase the RFS and OS of patients who suffered with HCC (125) (NCT00699816). Furthermore, adjuvant CIK cells treatments were proved to be safe and effective for HCC treatment by several meta-analyses (126-129).

In 2012, a phase II clinical study showed that CIK immunotherapy could enhance the efficacy of conventional chemotherapy in patients with NSCLC (130). Furthermore, Chen et al. proved the MHC class I-related chain A (MICA) status was also associated with the outcome measures in CIK therapy for patients with gastric cancer, for the patients with high expression of MICA were more likely to benefit from CIK therapy $(131,132)$. In a phase II/ III study, combined radiofrequency ablation with CIK has been reported to be a safe and effective treatment for CRLMs patients (133). Hereafter, many clinical studies were conducted to evaluate the efficacy of CIK/DC-CIK cell therapy for lung cancer, and all the results showed that CIK/DC-CIK was an effective therapy for lung cancer (134-139).

Many researches proved that CIK therapy was therapeutic for treatment of gastrointestinal tumors such as colorectal cancer and gastric cancer. In 2014, a meta-analysis in China showed that the combination of DC-CIK with chemotherapy could significantly improve the survival benefit, DFS rate, and overall response rate in patients with colon cancer. Furthermore, the number of $\mathrm{CD}^{+}$ T cells was significantly increased in the DC-CIK + chemotherapy group (98). Zhao et al. reported that CIK cells could improve OS of metastatic colorectal cancer patients in a phase II clinical trial (140). Lin et al. showed that DC-CIK combined with chemotherapy could prolong PFS and OS in colorectal cancer patients compared to chemotherapy alone (141). Mu et al. summarized 17 eligible trials including 1,735 patients with gastric cancer in a metaanalysis, and they found that the combination of chemotherapy with CIK/DC-CIK significantly increased the OS rate and DFS rate, enhanced immune function, and reduced the AEs caused by chemotherapy (97). Kong et al. showed that the addition of CIK cells immunotherapy to standard chemoradiotherapy with temozolomide improved PFS but not OS in a phase III randomized trial of newly diagnosed glioblastoma in Korea (142) (NCT00807027).

The clinical outcome of cancer with different pathologic stages is different, but little is known about the achievable outcome of CIK cells in patients with different pathological stages of the tumor. Recently, Li et al. reported that combined CIK with 
TABLE 1 | Clinical studies on cytokine-induced killer (CIK) cells.

\begin{tabular}{|c|c|c|c|c|c|}
\hline Trial & Phases & Experimental design & Target disease & Recruitment & Enrollment \\
\hline NCT01533727 & $\|$ & ClK + chemotherapy & Non-small-cell lung cancer (NSCLC) & Withdrawn & 0 \\
\hline NCT02539017 & $\|$ & Dendritic cell (DC)/CIK + chemotherapy & Triple-negative breast neoplasms & Withdrawn & 0 \\
\hline NCT01871480 & $\|$ & CIK + gefitinib & NSCLC & Terminated & 50 \\
\hline NCT01655628 & $\|$ & ClK + chemotherapy & Nasopharyngeal carcinoma & Recruiting & 40 \\
\hline NCT01902875 & Undefined & CIK + chemotherapy & NSCLC & Recruiting & 100 \\
\hline NCT01914263 & 1 & ClK & Solid tumor & Recruiting & 40 \\
\hline NCT01868490 & $|/| \mid$ & $\mathrm{CIK}$ & Cholangiocarcinoma & Recruiting & 13 \\
\hline NCT01186809 & $\|$ & CIK & Hematologic malignancies & Recruiting & 50 \\
\hline NCT01839539 & $\|$ & DC-CIK & Colorectal cancer & Recruiting & 60 \\
\hline NCT01799083 & $|/| \mid$ & Decitabine + CIK & Solid tumors/B cell lymphoma & Recruiting & 100 \\
\hline NCT00862303 & $1 / I I$ & DC-CIK & Renal cell carcinoma & Recruiting & 100 \\
\hline NCT02621333 & $\|$ & CIK + chemotherapy & Lung adenocarcinoma & Recruiting & 280 \\
\hline NCT02280278 & III & Radical surgery/adjuvant chemotherapy + CIK & Colon cancer & Recruiting & 550 \\
\hline NCT01592422 & $\|$ & $\mathrm{CIK}$ & Small-cell lung cancer & Recruiting & 60 \\
\hline NCT01498055 & $\|/\| I$ & $\mathrm{CIK}$ & Lung cancer & Recruiting & 120 \\
\hline NCT01481259 & $\|/\| I$ & $\mathrm{CIK}$ & NSCLC & Recruiting & 120 \\
\hline NCT02752243 & $1 / I I$ & $\mathrm{ClK}$ & $\begin{array}{l}\text { Myelodysplastic syndromes (MDSs)/acute } \\
\text { leukemia }\end{array}$ & Recruiting & 40 \\
\hline NCT02651441 & $1 / I I$ & DC-CIK + chemotherapy & NSCLC & Recruiting & 60 \\
\hline NCT02568748 & III & CIK & Advanced HCC & Recruiting & 20 \\
\hline NCT02487017 & $\|$ & $\mathrm{DC}-\mathrm{CIK}+\mathrm{TACE}$ & Hepatocellular carcinoma (HCC) & Recruiting & 60 \\
\hline NCT02644863 & $\|$ & DC-CIK + chemotherapy & Esophageal cancer & Recruiting & 60 \\
\hline NCT01691625 & Undefined & $\mathrm{DC}-\mathrm{CIK}$ & Esophageal cancer & Recruiting & 50 \\
\hline NCT01758679 & IV & Licartin + ClK & $\mathrm{HCC}$ & Recruiting & 120 \\
\hline NCT01783951 & $1 / I I$ & $\mathrm{~S}-1+\mathrm{DC}-\mathrm{ClK}$ & Gastric cancer & Recruiting & 30 \\
\hline NCT01781520 & $1 / I I$ & $\mathrm{~S}-1+\mathrm{DC}-\mathrm{CIK}$ & Pancreatic cancer & Recruiting & 30 \\
\hline NCT02504229 & $\|$ & DC-CIK + chemotherapy & Gastric cancer & Recruiting & 80 \\
\hline NCT01691664 & Undefined & Radiation therapy + DC-CIK & Esophageal cancer & Recruiting & 40 \\
\hline NCT01884168 & Undefined & $\mathrm{DC}-\mathrm{CIK}$ & Malignant tumor & Recruiting & 30 \\
\hline NCT01898793 & I & Chemotherapy + CIK & Leukemia, myeloid, acute & Recruiting & 24 \\
\hline NCT01906632 & Undefined & $\mathrm{DC}-\mathrm{CIK}$ & Malignant tumor & Recruiting & 50 \\
\hline NCT02851784 & $\|/\| I \|$ & Microwave ablation + CIK & $\mathrm{HCC}$ & Recruiting & 50 \\
\hline NCT01929499 & $\|$ & $\mathrm{ClK}$ & Colonic neoplasms & Not yet recruiting & 210 \\
\hline NCT01821495 & $\|$ & DC-CIK to treat NPC & Nasopharyngeal carcinoma & Not yet recruiting & 100 \\
\hline NCT02496988 & IV & Temozolomide + CIK & Advanced milignant gliomas & Not yet recruiting & 120 \\
\hline NCT02494804 & $\mathrm{l} / \mathrm{II}$ & Temozolomide + ClK & Milignant gliomas & Not yet recruiting & 80 \\
\hline NCT02490735 & $\|$ & CIK & Esophageal squamous cell carcinoma & Not yet recruiting & 2,000 \\
\hline NCT01631357 & $\|/\|$ & CIK + chemotherapy & Lung cancer & Not yet recruiting & 200 \\
\hline NCT01821482 & $\|$ & DC-CIK & $\mathrm{HCC}$ & Not yet recruiting & 100 \\
\hline NCT02497898 & $\|$ & ClK & Lymphoma, non-Hodgkin & Not yet recruiting & 1,000 \\
\hline NCT02487550 & $\|$ & DC-CIK & Renal neoplasma & Not yet recruiting & 1,200 \\
\hline NCT01235845 & $|/| I$ & DC-activated CIK + DC & Malignant glioma & Not yet recruiting & 30 \\
\hline NCT02415699 & $\|/\| \|$ & DC-CIK + chemotherapy & Colorectal cancer & Not yet recruiting & 100 \\
\hline NCT01240005 & $|/| \mid$ & $\mathrm{DC}-\mathrm{CIK}$ & Renal cell carcinoma & Not yet recruiting & 30 \\
\hline NCT01828008 & Undefined & CD20 antibody + CIK & Lymphomas & Not yet recruiting & 20 \\
\hline NCT02688686 & $|/ I|$ & Genetically modified DC + CIK & NSCLC with bone metastases & Not yet recruiting & 30 \\
\hline NCT02498756 & $\|$ & $\mathrm{CIK}+$ ipilimumab & Melanoma & Not yet recruiting & 300 \\
\hline NCT02585908 & $\mid / I I$ & $\mathrm{ClK}+\gamma \delta \mathrm{T}$ & Gastric cancer & Not yet recruiting & 120 \\
\hline NCT02856815 & $\|$ & ClK & Hepatocellular & Not yet recruiting & 78 \\
\hline NCT02782546 & $\|$ & CIML NK cell & Acute myeloid leukemia & Not yet recruiting & 60 \\
\hline NCT00769106 & III & $\mathrm{ClK}$ & $\mathrm{HCC}$ & Completed & 200 \\
\hline NCT02419677 & $\|/\| \|$ & Radiofrequency ablation + CIK & Colorectal cancer & Completed & 60 \\
\hline NCT00815321 & $\|$ & CIK & Chronic myeloid leukemia & Completed & 11 \\
\hline NCT00394381 & $|/| \mid$ & ClK & Acute myeloid leukemia/MDS & Completed & 17 \\
\hline NCT01749865 & III & $\mathrm{ClK}$ & Carcinoma, hepatocellular & Completed & 200 \\
\hline NCT00460694 & $\mid / I I$ & CIK & Hematological malignancies & Completed & 24 \\
\hline NCT00477035 & $|/| \mid$ & $\mathrm{CIK}$ & Hematologic malignancies & Completed & 22 \\
\hline NCT01232062 & Undefined & DC-CIK + chemotherapy & Triple-negative breast cancer & Completed & 46 \\
\hline NCT02406846 & Undefined & DC-CIK + cryosurgery & Neoplastic cells, circulating & Completed & 80 \\
\hline NCT02412384 & Undefined & DC-CIK + cryosurgery & Neoplastic cells, circulating & Completed & 120 \\
\hline NCT02450448 & Undefined & DC-CIK + cryosurgery & Neoplastic cells, circulating & Completed & 60 \\
\hline NCT02416635 & Undefined & $\mathrm{DC}-\mathrm{CIK}+$ cryosurgery & Neoplastic cells, circulating & Completed & 60 \\
\hline NCT02450357 & Undefined & DC-CIK + cryosurgery & Neoplastic cells, circulating & Completed & 60 \\
\hline
\end{tabular}


TABLE 1 | Continued

\begin{tabular}{|c|c|c|c|c|c|}
\hline Trial & Phases & Experimental design & Target disease & Recruitment & Enrollment \\
\hline NCT02450435 & Undefined & DC-CIK + cryosurgery & Neoplastic cells, circulating & Completed & 60 \\
\hline NCT02450422 & Undefined & DC-CIK + cryosurgery & Neoplastic cells, circulating & Completed & 60 \\
\hline NCT02425735 & $1 / 11$ & $\mathrm{DC}-\mathrm{CIK}+\gamma \delta \mathrm{T}$ & Liver cancer & Completed & 40 \\
\hline NCT00807027 & III & ClK + chemotherapy & Glioblastoma & Completed & 180 \\
\hline NCT01395056 & Undefined & DC-CIK + chemotherapy & Triple-negative breast cancer & Completed & 23 \\
\hline NCT02425748 & $|/| \mid$ & $\mathrm{DC}-\mathrm{CIK}+\gamma \delta \mathrm{T}$ & Lung cancer & Completed & 40 \\
\hline NCT02418481 & $1 / I 1$ & $\mathrm{DC}-\mathrm{CIK}+\gamma \delta \mathrm{T}$ & Breast cancer & Completed & 40 \\
\hline NCT00699816 & III & $\mathrm{ClK}$ & Hepatocelluar carcinoma & Completed & 230 \\
\hline NCT00186342 & Undefined & CIK & Hematologic malignancies & Completed & 120 \\
\hline NCT02482454 & $\|/ / I\|$ & Radiofrequency ablation + CIK & Cholangiocarcinoma & Active, not recruiting & 50 \\
\hline NCT01392989 & $\|$ & CIK + chemotherapy & MDSs & Active, not recruiting & 44 \\
\hline NCT02489890 & $\|$ & CIK & Urinary bladder neoplasms & Active, not recruiting & 1,500 \\
\hline NCT00185757 & । & CIK & Multiple myeloma & Active, not recruiting & 20 \\
\hline NCT02485015 & $\|$ & $\mathrm{CIK}+$ apatinib & Stomach neoplasms & Active, not recruiting & 80 \\
\hline NCT02490748 & $\|$ & Radiofrequency ablation + CIK & Cervical cancer & Active, not recruiting & 10 \\
\hline NCT02493582 & $\|$ & CIK + apatinib & Adenocarcinoma of lung & Active, not recruiting & 400 \\
\hline NCT02215837 & $\|$ & Chemotherapy + DC-CIK & Gastric cancer & Active, not recruiting & 40 \\
\hline NCT01924156 & $|/| \mid$ & adenovirus-transfected DC + CIK & Renal cell carcinoma & Active, not recruiting & 30 \\
\hline NCT01898663 & $\mid / I I$ & Adenovirus-transfected DC + CIK & High-risk soft tissue sarcoma & Active, not recruiting & 30 \\
\hline NCT02491697 & $\|$ & DC-CIK + capecitabine monotherapy & Breast cancer & Active, not recruiting & 400 \\
\hline NCT02487693 & $\|$ & Radiofrequency ablation + CIK & Ovarian carcinoma & Active, not recruiting & 50 \\
\hline NCT02487992 & $\|$ & ClK & Colorectal neoplasms & Active, not recruiting & 1,200 \\
\hline NCT02693236 & $1 / I 1$ & adenovirus-transfected autologous DC + CIK & Esophagus cancer & Active, not recruiting & 30 \\
\hline NCT02202928 & $\|$ & DC-CIK + chemotherapy & Colorectal cancer & Active, not recruiting & 60 \\
\hline NCT01956630 & $|/| \mid$ & DC-CIK & Acute leukemia & Active, not recruiting & 25 \\
\hline NCT02688673 & $|/| \mid$ & DC-CIK & Small-cell lung cancer & Active, not recruiting & 30 \\
\hline NCT02678013 & III & RFA + highly purified cytotoxic T lymphocytes & $\mathrm{HCC}$ & Active, not recruiting & 210 \\
\hline
\end{tabular}

These data were searched on 11 August, 2016 from the ClinicalTrials.gov (http://www.clinicaltrials.gov) using the word "cytokine-induced killer cells OR CIK."

conventional treatments could increase the survival rate of earlystage melanoma patients (143). So, whether the outcome of CIK is better in early-stage patient needs to be further studied.

As we have seen, most of the CIK registered clinical trials are restricted to Asian countries (64 trials), so it is difficult to completely evaluate the effects of CIK therapy over the world. Besides, the number of patients included in some clinical trials is also inadequate. So, more large-scale, grouped, controlled, multicenter, non-commercial clinical trials are required to confirm the immunotherapeutic effects of CIK in cancer treatment.

\section{CONCLUSION AND PROSPECTS}

In recent years, immunotherapy is considered to be a powerful pharmacological tool for the treatment of many malignancies (144). It is known that the expression of tumor antigens and MHC-I molecules are often downregulated or completely lost on tumor cells. Although the TILs could recognize specific antigens expressed by autologous tumor cells, this specific antigenicity is too low to achieve a high degree of antigenicity in therapeutic use $(120,145)$. What is more, the extremely low numbers of TIL cells and lymphokine-activated killer (LAK) cells also restrict their application. Compared to LAK cells, the CIK cells exhibit a relative higher proliferation rate and stronger antitumor activity. Especially for their non-MHC-restricted characteristic, CIK cells have a much broader antitumor spectrum. Antibody-based therapy and CAR-T cell therapy for cancer have been demonstrated to be one of the most successful and important treatment strategies, but there are still some details to be improved. One of the key challenges is to identify suitable antigens of tumors with explicit target genes. Unfortunately, the presence of intrinsic or acquired resistance has blunted the advantages of targeted therapies, the reason is partially due to the mutation or downregulation of specific antigen (79). The immune checkpoint blockade shows impressive clinical results, but the majority of patients are either resistant or relapse after therapy (146). Based on these data, optimal adoptive cellular immunotherapy (ACI) may require a portfolio of different treatment strategies.

As mentioned earlier, CIK cells are a heterogeneous population of $\mathrm{CD}^{+} \mathrm{T}$ lymphocytes, which maybe not only the biggest drawback but also the biggest advantage of this method. As a heterogeneous cell population, CIK cells are proved to contain different subpopulations and present a mixed T-NK phenotype. Until now, the precise subpopulation that is the most crucial and relevant to the clinical outcome and the exact pharmacological mechanism of how CIK kill tumor cells are still not completely understood. So, it is hard to precisely evaluate the effect of the CIK cell on immune response in cancer patients and hard to know why some clinical trials with CIK failed. Clearly, this uncertainty limits the clinical application of CIK. In contrast, as a heterogeneous cell population, CIK cells are able to kill heterogeneous tumor cells despite the tumor heterogeneity and antigen escape, which are major setbacks for the antibody-based and CART immunotherapy (147). And this may be the biggest advantage of CIK therapy. CIK cells therapy can improve the prognosis of cancer patients for its safety and decreased recurrence, so it 
would be the most effective treatment on residual cancer cells after conventional therapy.

Recently, much effort has been made to improve the antitumor activity of CIK cells and the recent findings of clinical applicability are reviewed in the paper. The promising outcomes have been made by CIK cells therapy combined with other therapies. But further research is still needed to optimize the procedure of CIK therapy. First, uniform culturing criteria should be formulated for CIK expansion. Second, more clinical trials need to be conducted with large-scale, controlled, grouped patients, including patients with different tumor stages and different cancer biomarkers. Only by doing these, can we figure out the tumor-killing mechanism of CIK cells and better evaluate their clinical efficacy.

More and more people realize that it is hard to cure cancer with only one drug or one therapeutic strategy. The combination of different drugs or therapies has already become a trend in treating heterogeneous tumors. As an effective ACI, CIK cells therapy provide a chance to prolong survival of cancer patients in clinical practice, and it is definitely worthy to spend more effort on it.

\section{REFERENCES}

1. Bray F, Jemal A, Grey N, Ferlay J, Forman D. Global cancer transitions according to the Human Development Index (2008-2030): a population-based study. Lancet Oncol (2012) 13(8):790-801. doi:10.1016/ S1470-2045(12)70211-5

2. Ferlay J, Shin HR, Bray F, Forman D, Mathers C, Parkin DM. Estimates of worldwide burden of cancer in 2008: GLOBOCAN 2008. Int J Cancer (2010) 127(12):2893-917. doi:10.1002/ijc.25516

3. Yron I, Wood TA Jr, Spiess PJ, Rosenberg SA. In vitro growth of murine T cells. V. The isolation and growth of lymphoid cells infiltrating syngeneic solid tumors. J Immunol (1980) 125(1):238-45.

4. Lotze MT, Line BR, Mathisen DJ, Rosenberg SA. The in vivo distribution of autologous human and murine lymphoid cells grown in $\mathrm{T}$ cell growth factor (TCGF): implications for the adoptive immunotherapy of tumors. J Immunol (1980) 125(4):1487-93.

5. Schmidt-Wolf IG, Negrin RS, Kiem HP, Blume KG, Weissman IL. Use of a SCID mouse/human lymphoma model to evaluate cytokine-induced killer cells with potent antitumor cell activity. J Exp Med (1991) 174(1):139-49. doi:10.1084/jem.174.1.139

6. Schmidt-Wolf IG, Lefterova P, Mehta BA, Fernandez LP, Huhn D, Blume KG, et al. Phenotypic characterization and identification of effector cells involved in tumor cell recognition of cytokine-induced killer cells. Exp Hematol (1993) 21(13):1673-9.

7. Kaneko T, Fusauch Y, Kakui Y, Okumura K, Mizoguchi H, Oshimi K. Cytotoxicity of cytokine-induced killer cells coated with bispecific antibody against acute myeloid leukemia cells. Leuk Lymphoma (1994) 14(3-4):219-29. doi:10.3109/10428199409049672

8. Zoll B, Lefterova P, Csipai M, Finke S, Trojaneck B, Ebert O, et al. Generation of cytokine-induced killer cells using exogenous interleukin-2, -7 or -12. Cancer Immunol Immunother (1998) 47(4):221-6. doi:10.1007/ s002620050524

9. Schmidt-Wolf IG, Finke S, Trojaneck B, Denkena A, Lefterova P, Schwella N, et al. Phase I clinical study applying autologous immunological effector cells transfected with the interleukin-2 gene in patients with metastatic renal cancer, colorectal cancer and lymphoma. Br J Cancer (1999) 81(6):1009-16. doi:10.1038/sj.bjc.6690800

10. Marten A, Ziske C, Schottker B, Renoth S, Weineck S, Buttgereit P, et al. Interactions between dendritic cells and cytokine-induced killer cells lead to an activation of both populations. J Immunother (2001) 24(6):502-10. doi:10.1097/00002371-200111000-00007

\section{AUTHOR CONTRIBUTIONS}

XG, YM, and WJ conceived this study. XG and NG wrote the manuscript. HX and LX provided critical discussion in manuscript preparation. LX and WJ revised the manuscript. All the authors reviewed this manuscript.

\section{FUNDING}

This work was supported by the National Natural Science Foundation of China (Nos. 81402063, 31400913, 81601376, and 81402850), China Postdoctoral Science Foundation funded project (2016M), the Leading Disciplines Development Government Foundation of Shaanxi, China, University's key disciplines of molecular immunology, Doctoral research start-up fund project of Xi'an Medical University (Program Nos. 2015DOC07 and 2015DOC08). The Project was supported by the Natural Science Basic Research Plan in Shaanxi Province of China (No. 2017JM8086) and Scientific Research Program Funded by Shaanxi Provincial Education Department (15JK1636, 16JK1655).

11. Verneris MR, Karimi M, Baker J, Jayaswal A, Negrin RS. Role of NKG2D signaling in the cytotoxicity of activated and expanded CD8+ T cells. Blood (2004) 103(8):3065-72. doi:10.1182/blood-2003-06-2125

12. Jiang J, Xu N, Wu C, Deng H, Lu M, Li M, et al. Treatment of advanced gastric cancer by chemotherapy combined with autologous cytokine-induced killer cells. Anticancer Res (2006) 26(3B):2237-42.

13. Contag CH, Sikorski R, Negrin RS, Schmidt T, Fan AC, Bachireddy P, et al. Definition of an enhanced immune cell therapy in mice that can target stemlike lymphoma cells. Cancer Res (2010) 70(23):9837-45. doi:10.1158/00085472.CAN-10-2650

14. Hontscha C, Borck Y, Zhou H, Messmer D, Schmidt-Wolf IG. Clinical trials on CIK cells: first report of the international registry on CIK cells (IRCC). J Cancer Res Clin Oncol (2011) 137(2):305-10. doi:10.1007/ s00432-010-0887-7

15. Schlimper C, Hombach AA, Abken H, Schmidt-Wolf IG. Improved activation toward primary colorectal cancer cells by antigen-specific targeting autologous cytokine-induced killer cells. Clin Dev Immunol (2012) 2012:238924. doi:10.1155/2012/238924

16. Dai C, Lin F, Geng R, Ge X, Tang W, Chang J, et al. Implication of combined PD-L1/PD-1 blockade with cytokine-induced killer cells as a synergistic immunotherapy for gastrointestinal cancer. Oncotarget (2016) 7(9):10332-44. doi:10.18632/oncotarget.7243

17. Lee HK, Kim YG, Kim JS, Park EJ, Kim B, Park KH, et al. Cytokine-induced killer cells interact with tumor lysate-pulsed dendritic cells via CCR5 signaling. Cancer Lett (2016) 378(2):142-9. doi:10.1016/j.canlet.2016.05.020

18. Linn YC, Lau LC, Hui KM. Generation of cytokine-induced killer cells from leukaemic samples with in vitro cytotoxicity against autologous and allogeneic leukaemic blasts. Br J Haematol (2002) 116(1):78-86. doi:10.1046/j.1365-2141.2002.03247.x

19. Schmidt TL, Negrin RS, Contag CH. A killer choice for cancer immunotherapy. Immunol Res (2014) 58(2-3):300-6. doi:10.1007/s12026-014-8507-2

20. Pievani A, Belussi C, Klein C, Rambaldi A, Golay J, Introna M. Enhanced killing of human B-cell lymphoma targets by combined use of cytokine-induced killer cell (CIK) cultures and anti-CD20 antibodies. Blood (2011) 117(2):510-8. doi:10.1182/blood-2010-06-290858

21. Linn YC, Wang SM, Hui KM. Comparative gene expression profiling of cytokine-induced killer cells in response to acute myloid leukemic and acute lymphoblastic leukemic stimulators using oligonucleotide arrays. Exp Hematol (2005) 33(6):671-81. doi:10.1016/j.exphem.2005.03.005

22. Sangiolo D. Cytokine induced killer cells as promising immunotherapy for solid tumors. J Cancer (2011) 2:363-8. doi:10.7150/jca.2.363 
23. Lu PH, Negrin RS. A novel population of expanded human CD3+CD56+ cells derived from $T$ cells with potent in vivo antitumor activity in mice with severe combined immunodeficiency. J Immunol (1994) 153(4):1687-96.

24. Introna M, Franceschetti M, Ciocca A, Borleri G, Conti E, Golay J, et al. Rapid and massive expansion of cord blood-derived cytokine-induced killer cells: an innovative proposal for the treatment of leukemia relapse after cord blood transplantation. Bone Marrow Transplant (2006) 38(9):621-7. doi:10.1038/ sj.bmt.1705503

25. Todorovic M, Mesiano G, Gammaitoni L, Leuci V, Giraudo Diego L, Cammarata C, et al. Ex vivo allogeneic stimulation significantly improves expansion of cytokine-induced killer cells without increasing their alloreactivity across HLA barriers. J Immunother (2012) 35(7):579-86. doi:10.1097/ CJI.0b013e31826b1fd9

26. Hayes MP, Wang J, Norcross MA. Regulation of interleukin-12 expression in human monocytes: selective priming by interferon-gamma of lipopolysaccharide-inducible p35 and p40 genes. Blood (1995) 86(2):646-50.

27. Ma X, Chow JM, Gri G, Carra G, Gerosa F, Wolf SF, et al. The interleukin 12 p40 gene promoter is primed by interferon gamma in monocytic cells. J Exp Med (1996) 183(1):147-57. doi:10.1084/jem.183.1.147

28. Lopez RD, Waller EK, Lu PH, Negrin RS. CD58/LFA-3 and IL-12 provided by activated monocytes are critical in the in vitro expansion of CD56+ T cells. Cancer Immunol Immunother (2001) 49(12):629-40. doi:10.1007/ s002620000148

29. Ochoa AC, Gromo G, Alter BJ, Sondel PM, Bach FH. Long-term growth of lymphokine-activated killer (LAK) cells: role of anti-CD3, beta-IL 1, interferon-gamma and -beta. J Immunol (1987) 138(8):2728-33.

30. Anderson PM, Bach FH, Ochoa AC. Augmentation of cell number and LAK activity in peripheral blood mononuclear cells activated with anti-CD3 and interleukin-2. Preliminary results in children with acute lymphocytic leukemia and neuroblastoma. Cancer Immunol Immunother (1988) 27(1):82-8. doi:10.1007/BF00205763

31. Leemhuis T, Wells S, Scheffold C, Edinger M, Negrin RS. A phase I trial of autologous cytokine-induced killer cells for the treatment of relapsed Hodgkin disease and non-Hodgkin lymphoma. Biol Blood Marrow Transplant (2005) 11(3):181-7. doi:10.1016/j.bbmt.2004.11.019

32. Baker J, Verneris MR, Ito M, Shizuru JA, Negrin RS. Expansion of cytolytic CD8(+) natural killer $\mathrm{T}$ cells with limited capacity for graft-versus-host disease induction due to interferon gamma production. Blood (2001) 97(10):2923-31. doi:10.1182/blood.V97.10.2923

33. Li XD, Xu B, Wu J, Ji M, Xu BH, Jiang JT, et al. Review of Chinese clinical trials on CIK cell treatment for malignancies. Clin Transl Oncol (2012) 14(2):102-8. doi:10.1007/s12094-012-0768-4

34. Cohen JE, Merims S, Frank S, Engelstein R, Peretz T, Lotem M. Adoptive cell therapy: past, present and future. Immunotherapy (2017) 9(2):183-96. doi:10.2217/imt-2016-0112

35. Bonanno G, Iudicone P, Mariotti A, Procoli A, Pandolfi A, Fioravanti D, et al. Thymoglobulin, interferon-gamma and interleukin-2 efficiently expand cytokine-induced killer (CIK) cells in clinical-grade cultures. J Transl Med (2010) 8:129. doi:10.1186/1479-5876-8-129

36. Rettinger E, Kuci S, Naumann I, Becker P, Kreyenberg H, Anzaghe M, et al. The cytotoxic potential of interleukin-15-stimulated cytokine-induced killer cells against leukemia cells. Cytotherapy (2012) 14(1):91-103. doi:10.3109/1 4653249.2011.613931

37. Mosinska P, Gabryelska A, Zasada M, Fichna J. Dual functional capability of dendritic cells - cytokine-induced killer cells in improving side effects of colorectal cancer therapy. Front Pharmacol (2017) 8:126. doi:10.3389/ fphar.2017.00126

38. Laport GG, Sheehan K, Baker J, Armstrong R, Wong RM, Lowsky R, et al. Adoptive immunotherapy with cytokine-induced killer cells for patients with relapsed hematologic malignancies after allogeneic hematopoietic cell transplantation. Biol Blood Marrow Transplant (2011) 17(11):1679-87. doi:10.1016/j.bbmt.2011.05.012

39. Linn YC, Niam M, Chu S, Choong A, Yong HX, Heng KK, et al. The anti-tumour activity of allogeneic cytokine-induced killer cells in patients who relapse after allogeneic transplant for haematological malignancies. Bone Marrow Transplant (2012) 47(7):957-66. doi:10.1038/bmt.2011.202

40. Introna M, Borleri G, Conti E, Franceschetti M, Barbui AM, Broady R, et al. Repeated infusions of donor-derived cytokine-induced killer cells in patients relapsing after allogeneic stem cell transplantation: a phase I study. Haematologica (2007) 92(7):952-9. doi:10.3324/haematol.11132

41. Li Y, Schmidt-Wolf IG, Wu YF, Huang SL, Wei J, Fang J, et al. Optimized protocols for generation of cord blood-derived cytokine-induced killer/ natural killer cells. Anticancer Res (2010) 30(9):3493-9.

42. Zhang Z, Zhao X, Zhang T, Wang L, Yang L, Huang L, et al. Phenotypic characterization and anti-tumor effects of cytokine-induced killer cells derived from cord blood. Cytotherapy (2015) 17(1):86-97. doi:10.1016/j. jcyt.2014.09.006

43. Zhang Z, Wang L, Luo Z, Zhao X, Huang J, Li H, et al. Efficacy and safety of cord blood-derived cytokine-induced killer cells in treatment of patients with malignancies. Cytotherapy (2015) 17(8):1130-8. doi:10.1016/j. jcyt.2015.04.002

44. Niu Q, Wang W, Li Y, Qin S, Wang Y, Wan G, et al. Cord blood-derived cytokine-induced killer cells biotherapy combined with second-line chemotherapy in the treatment of advanced solid malignancies. Int Immunopharmacol (2011) 11(4):449-56. doi:10.1016/j.intimp.2010.12.014

45. Thanendrarajan S, Kim Y, Schmidt-Wolf I. New adoptive immunotherapy strategies for solid tumours with CIK cells. Expert Opin Biol Ther (2012) 12(5):565-72. doi:10.1517/14712598.2012.668879

46. Jakel CE, Schmidt-Wolf IG. An update on new adoptive immunotherapy strategies for solid tumors with cytokine-induced killer cells. Expert Opin Biol Ther (2014) 14(7):905-16. doi:10.1517/14712598.2014.900537

47. Lin G, Wang J, Lao X, Li L, Li S, Zhang J, et al. Interleukin-6 inhibits regulatory $\mathrm{T}$ cells and improves the proliferation and cytotoxic activity of cytokine-induced killer cells. J Immunother (2012) 35(4):337-43. doi:10.1097/ CJI.0b013e318255ada3

48. Finke S, Trojaneck B, Lefterova P, Csipai M, Wagner E, Kircheis R, et al. Increase of proliferation rate and enhancement of antitumor cytotoxicity of expanded human CD3+ CD56+ immunologic effector cells by receptormediated transfection with the interleukin-7 gene. Gene Ther (1998) 5(1):31-9. doi:10.1038/sj.gt.3300560

49. Zoll B, Lefterova P, Ebert O, Huhn D, Von Ruecker A, Schmidt-Wolf IG. Modulation of cell surface markers on NK-like T lymphocytes by using IL-2, IL-7 or IL-12 in vitro stimulation. Cytokine (2000) 12(9):1385-90. doi:10.1006/ cyto.2000.0733

50. Yang Z, Zhang Q, Xu K, Shan J, Shen J, Liu L, et al. Combined therapy with cytokine-induced killer cells and oncolytic adenovirus expressing IL-12 induce enhanced antitumor activity in liver tumor model. PLoS One (2012) 7(9):e44802. doi:10.1371/journal.pone.0044802

51. Tao Q, Chen T, Tao L, Wang H, Pan Y, Xiong S, et al. IL-15 improves the cytotoxicity of cytokine-induced killer cells against leukemia cells by upregulating CD3+CD56+ cells and downregulating regulatory T cells as well as IL-35. J Immunother (2013) 36(9):462-7. doi:10.1097/CJI.0000000000000001

52. Wei C, Wang W, Pang W, Meng M, Jiang L, Xue S, et al. The CIK cells stimulated with combination of IL-2 and IL-15 provide an improved cytotoxic capacity against human lung adenocarcinoma. Tumour Biol (2014) 35(3):1997-2007. doi:10.1007/s13277-013-1265-2

53. Peng Z, Liang W, Li Z, Xu Y, Chen L. Interleukin-15-transferred cytokine-induced killer cells elevated anti-tumor activity in a gastric tumor-bearing nude mice model. Cell Biol Int (2016) 40(2):204-13. doi:10.1002/cbin.10553

54. Cappel C, Huenecke S, Suemmerer A, Erben S, Rettinger E, Pfirrmann V, et al. Cytotoxic potential of IL-15-activated cytokine-induced killer cells against human neuroblastoma cells. Pediatr Blood Cancer (2016) 63(12):2230-9. doi: $10.1002 / \mathrm{pbc} .26147$

55. Iudicone P, Fioravanti D, Cicchetti E, Zizzari IG, Pandolfi A, Scocchera R, et al. Interleukin-15 enhances cytokine induced killer (CIK) cytotoxic potential against epithelial cancer cell lines via an innate pathway. Hum Immunol (2016) 77(12):1239-47. doi:10.1016/j.humimm.2016.09.003

56. Cai C, Chen W, Miao D, Cheng L, Yang G, Zhang L, et al. Toll-like receptor 4 is required for the cytotoxicity of cytokine-induced killer cells. Acta Haematol (2014) 132(1):5-9. doi:10.1159/000355190

57. Wang W, Meng M, Zhang Y, Wei C, Xie Y, Jiang L, et al. Global transcriptome-wide analysis of CIK cells identify distinct roles of IL-2 and IL-15 in acquisition of cytotoxic capacity against tumor. BMC Med Genomics (2014) 7:49. doi:10.1186/1755-8794-7-49

58. Rajbhandary S, Zhao MF, Zhao N, Lu WY, Zhu HB, Xiao X, et al. Multiple cytotoxic factors involved in IL-21 enhanced antitumor function of CIK cells 
signaled through STAT-3 and STAT5b pathways. Asian Pac J Cancer Prev (2013) 14(10):5825-31. doi:10.7314/APJCP.2013.14.10.5825

59. Zhao N, Zhao MF, Rajbhandary S, Lu WY, Zhu HB, Ma L, et al. Effects and mechanism on anti-leukemic activity of cytokine-induced killer cells with an endogenous expression of interleukin-21. Zhonghua Yi Xue Za Zhi (2013) 93(4):293-9. doi:10.3760/cma.j.issn.0376-2491.2013.04.013

60. Banchereau J, Steinman RM. Dendritic cells and the control of immunity. Nature (1998) 392(6673):245-52. doi:10.1038/32588

61. Anguille S, Smits EL, Bryant C, Van Acker HH, Goossens H, Lion E, et al. Dendritic cells as pharmacological tools for cancer immunotherapy. Pharmacol Rev (2015) 67(4):731-53. doi:10.1124/pr.114.009456

62. Fernandez NC, Lozier A, Flament C, Ricciardi-Castagnoli P, Bellet D, Suter M, et al. Dendritic cells directly trigger NK cell functions: cross-talk relevant in innate anti-tumor immune responses in vivo. Nat Med (1999) 5(4):405-11. doi:10.1038/7403

63. Nicol A, Nieda M, Koezuka Y, Porcelli S, Suzuki K, Tadokoro K, et al. Human invariant valpha24+ natural killer $\mathrm{T}$ cells activated by alphagalactosylceramide (KRN7000) have cytotoxic anti-tumour activity through mechanisms distinct from T cells and natural killer cells. Immunology (2000) 99(2):229-34. doi:10.1046/j.1365-2567.2000.00952.x

64. Cao J, Chen C, Wang Y, Chen X, Chen Z, Luo X. Influence of autologous dendritic cells on cytokine-induced killer cell proliferation, cell phenotype and antitumor activity in vitro. Oncol Lett (2016) 12(3):2033-7. doi:10.3892/ ol.2016.4839

65. Pan Y, Tao Q, Wang H, Xiong S, Zhang R, Chen T, et al. Dendritic cells decreased the concomitant expanded Tregs and Tregs related IL-35 in cytokine-induced killer cells and increased their cytotoxicity against leukemia cells. PLoS One (2014) 9(4):e93591. doi:10.1371/journal.pone.0093591

66. Cui Y, Yang X, Zhu W, Li J, Wu X, Pang Y. Immune response, clinical outcome and safety of dendritic cell vaccine in combination with cytokine-induced killer cell therapy in cancer patients. Oncol Lett (2013) 6(2):537-41. doi:10.3892/ol.2013.1376

67. Shan CC, Shi LR, Ding MQ, Zhu YB, Li XD, Xu B, et al. Cytokine-induced killer cells co-cultured with dendritic cells loaded with the protein lysate produced by radiofrequency ablation induce a specific antitumor response. Oncol Lett (2015) 9(4):1549-56. doi:10.3892/ol.2015.2977

68. Wang YF, Kunda PE, Lin JW, Wang H, Chen XM, Liu QL, et al. Cytokineinduced killer cells co-cultured with complete tumor antigen-loaded dendritic cells, have enhanced selective cytotoxicity on carboplatin-resistant retinoblastoma cells. Oncol Rep (2013) 29(5):1841-50. doi:10.3892/or.2013.2315

69. Liu Y, Liu H, He P, Li J, Liu X, Chen L, et al. Dendritic cell-activated cytokine-induced killer cell-mediated immunotherapy is safe and effective for cancer patients $>65$ years old. Oncol Lett (2016) 12(6):5205-10. doi:10.3892/ ol.2016.5337

70. Jung NC, Lee JH, Choi HJ, Hwang SU, Song JY, Seo HG, et al. Dendritic cell immunotherapy combined with cytokine-induced killer cells effectively suppresses established hepatocellular carcinomas in mice. Immunol Invest (2016) 45(6):553-65. doi:10.1080/08820139.2016.1183025

71. Lin M, Liang S, Jiang F, Xu J, Zhu W, Qian W, et al. 2003-2013, a valuable study: autologous tumor lysate-pulsed dendritic cell immunotherapy with cytokine-induced killer cells improves survival in stage IV breast cancer. Immunol Lett (2017) 183:37-43. doi:10.1016/j.imlet.2017.01.014

72. Chen DS, Mellman I. Oncology meets immunology: the cancer-immunity cycle. Immunity (2013) 39(1):1-10. doi:10.1016/j.immuni.2013.07.012

73. Preusser M, Lim M, Hafler DA, Reardon DA, Sampson JH. Prospects of immune checkpoint modulators in the treatment of glioblastoma. Nat Rev Neurol (2015) 11(9):504-14. doi:10.1038/nrneurol.2015.139

74. Driessens G, Kline J, Gajewski TF. Costimulatory and coinhibitory receptors in anti-tumor immunity. Immunol Rev (2009) 229(1):126-44. doi:10.1111/j.1600-065X.2009.00771.x

75. Pardoll DM. The blockade of immune checkpoints in cancer immunotherapy. Nat Rev Cancer (2012) 12(4):252-64. doi:10.1038/nrc3239

76. Vinay DS, Ryan EP, Pawelec G, Talib WH, Stagg J, Elkord E, et al. Immune evasion in cancer: mechanistic basis and therapeutic strategies. Semin Cancer Biol (2015) 35(Suppl):S185-98. doi:10.1016/j.semcancer.2015.03.004

77. Poh SL, Linn YC. Immune checkpoint inhibitors enhance cytotoxicity of cytokine-induced killer cells against human myeloid leukaemic blasts. Cancer Immunol Immunother (2016) 65(5):525-36. doi:10.1007/ s00262-016-1815-8
78. Sievers EL, Senter PD. Antibody-drug conjugates in cancer therapy. Annu Rev Med (2013) 64:15-29. doi:10.1146/annurev-med-050311-201823

79. Scott AM, Wolchok JD, Old LJ. Antibody therapy of cancer. Nat Rev Cancer (2012) 12(4):278-87. doi:10.1038/nrc3236

80. Deng QI, Bai X, Lv HR, Xiao X, Zhao MF, Li YM. Anti-CD20 antibody induces the improvement of cytokine-induced killer cell activity via the STAT and MAPK/ERK signaling pathways. Exp Ther Med (2015) 9(4):1215-22. doi:10.3892/etm.2015.2264

81. Esser L, Weiher H, Schmidt-Wolf I. Increased efficacy of brentuximab vedotin (SGN-35) in combination with cytokine-induced killer cells in lymphoma. Int J Mol Sci (2016) 17(7):E1056. doi:10.3390/ijms17071056

82. Fan G, Wang Z, Hao M, Li J. Bispecific antibodies and their applications. J Hematol Oncol (2015) 8:130. doi:10.1186/s13045-015-0227-0

83. Tita-Nwa F, Moldenhauer G, Herbst M, Kleist C, Ho AD, Kornacker M. Cytokine-induced killer cells targeted by the novel bispecific antibody CD19xCD5(HD37xT5.16) efficientlylyse B-lymphomacells. CancerImmunol Immunother (2007) 56(12):1911-20. doi:10.1007/s00262-007-0333-0

84. Chan JK, Hamilton CA, Cheung MK, Karimi M, Baker J, Gall JM, et al. Enhanced killing of primary ovarian cancer by retargeting autologous cytokine-induced killer cells with bispecific antibodies: a preclinical study. Clin Cancer Res (2006) 12(6):1859-67. doi:10.1158/1078-0432.CCR-05-2019

85. Zhang L, Hou Y, Zhang J, Hu J, Zhang K. Cytotoxicity of cytokine-induced killer cells targeted by a bispecific antibody to gastric cancer cells. Oncol Lett (2013) 5(6):1826-32. doi:10.3892/ol.2013.1281

86. Huang J, Li C, Wang Y, Lv H, Guo Y, Dai H, et al. Cytokine-induced killer (CIK) cells bound with anti-CD3/anti-CD133 bispecific antibodies target CD133(high) cancer stem cells in vitro and in vivo. Clin Immunol (2013) 149(1):156-68. doi:10.1016/j.clim.2013.07.006

87. Ma P, He Q, Li W, Li X, Han H, Jin M, et al. Anti-CD3 x EGFR bispecific antibody redirects cytokine-induced killer cells to glioblastoma in vitro and in vivo. Oncol Rep (2015) 34(5):2567-75. doi:10.3892/or.2015.4233

88. Oelsner S, Wagner J, Friede ME, Pfirrmann V, Genssler S, Rettinger E, et al. CAR-engineered cytokine-induced killer cells overcome treatment resistance of pre-B-ALL and enhance survival. Int J Cancer (2016) 139(8):1799-809. doi:10.1002/ijc.30217

89. Marin V, Dander E, Biagi E, Introna M, Fazio G, Biondi A, et al. Characterization of in vitro migratory properties of anti-CD19 chimeric receptor-redirected CIK cells for their potential use in B-ALL immunotherapy. Exp Hematol (2006) 34(9):1219-29. doi:10.1016/j.exphem.2006.05.004

90. Marin V, Kakuda H, Dander E, Imai C, Campana D, Biondi A, et al. Enhancement of the anti-leukemic activity of cytokine induced killer cells with an anti-CD19 chimeric receptor delivering a 4-1BB-zeta activating signal. Exp Hematol (2007) 35(9):1388-97. doi:10.1016/j.exphem.2007.05.018

91. Hombach AA, Rappl G, Abken H. Arming cytokine-induced killer cells with chimeric antigen receptors: CD28 outperforms combined CD28-OX40 "super-stimulation". Mol Ther (2013) 21(12):2268-77. doi:10.1038/ mt.2013.192

92. Wu C, Jiang J, Shi L, Xu N. Prospective study of chemotherapy in combination with cytokine-induced killer cells in patients suffering from advanced non-small cell lung cancer. Anticancer Res (2008) 28(6B):3997-4002.

93. Niethammer AG, Wodrich $H$, Loeffler $M$, Lode HN, Emmerich $K$, Abdollahi A, et al. Multidrug resistance-1 (MDR-1): a new target for T cellbased immunotherapy. FASEB J (2005) 19(1):158-9. doi:10.1096/f.04-2355fje

94. Liu P, Chen L, Huang X. The antitumor effects of CIK cells combined with docetaxel against drug-resistant lung adenocarcinoma cell line SPC-A1/ DTX in vitro and in vivo. Cancer Biother Radiopharm (2009) 24(1):91-8. doi:10.1089/cbr.2008.0533

95. Zheng C, Yu G, Wang H, Tang A, Geng P, Zhang H, et al. Meta-analysis of chemotherapy and dendritic cells with cytokine-induced killer cells in the treatment of non-small-cell lung cancer. Int J Clin Exp Med (2015) 8(8):14527-37.

96. Han RX, Liu X, Pan P, Jia YJ, Yu JC. Effectiveness and safety of chemotherapy combined with dendritic cells co-cultured with cytokine-induced killer cells in the treatment of advanced non-small-cell lung cancer: a systematic review and meta-analysis. PLoS One (2014) 9(9):e108958. doi:10.1371/journal. pone. 0108958

97. Mu Y, Zhou CH, Chen SF, Ding J, Zhang YX, Yang YP, et al. Effectiveness and safety of chemotherapy combined with cytokine-induced killer cell/ dendritic cell-cytokine-induced killer cell therapy for treatment of gastric 
cancer in China: a systematic review and meta-analysis. Cytotherapy (2016) 18(9):1162-77. doi:10.1016/j.jcyt.2016.05.015

98. Wang ZX, Cao JX, Liu ZP, Cui YX, Li CY, Li D, et al. Combination of chemotherapy and immunotherapy for colon cancer in China: a meta-analysis. World J Gastroenterol (2014) 20(4):1095-106. doi:10.3748/ wjg.v20.i4.1095

99. Liang C, Xu L, Song G, Liu Z. Emerging nanomedicine approaches fighting tumor metastasis: animal models, metastasis-targeted drug delivery, phototherapy, and immunotherapy. Chem Soc Rev (2016) 45(22):6250-69. doi: $10.1039 / c 6 c s 00458 j$

100. Ferrari M. Cancer nanotechnology: opportunities and challenges. Nat Rev Cancer (2005) 5(3):161-71. doi:10.1038/nrc1566

101. Phan JH, Moffitt RA, Stokes TH, Liu J, Young AN, Nie S, et al. Convergence of biomarkers, bioinformatics and nanotechnology for individualized cancer treatment. Trends Biotechnol (2009) 27(6):350-8. doi:10.1016/j. tibtech.2009.02.010

102. Cuenca AG, Jiang H, Hochwald SN, Delano M, Cance WG, Grobmyer SR. Emerging implications of nanotechnology on cancer diagnostics and therapeutics. Cancer (2006) 107(3):459-66. doi:10.1002/cncr.22035

103. Jin W, Cui D. Cancer nano-immunoengineering: the marriage of immunoengineering and nanotechnology for cancer. Nano Biomed Eng (2016) 8(2):105-6. doi:10.5101/nbe.v8i2.p105-107

104. Sanvicens N, Marco MP. Multifunctional nanoparticles - properties and prospects for their use in human medicine. Trends Biotechnol (2008) 26(8):425-33. doi:10.1016/j.tibtech.2008.04.005

105. Yezhelyev MV, Gao X, Xing Y, Al-Hajj A, Nie S, O’Regan RM. Emerging use of nanoparticles in diagnosis and treatment of breast cancer. Lancet Oncol (2006) 7(8):657-67. doi:10.1016/S1470-2045(06)70793-8

106. Swai H, Semete B, Kalombo L, Chelule P, Kisich K, Sievers B. Nanomedicine for respiratory diseases. Wiley Interdiscip Rev Nanomed Nanobiotechnol (2009) 1(3):255-63. doi:10.1002/wnan.33

107. Pison U, Welte T, Giersig M, Groneberg DA. Nanomedicine for respiratory diseases. Eur JPharmacol (2006) 533(1-3):341-50. doi:10.1016/j. ejphar.2005.12.068

108. Irvine DJ, Hanson MC, Rakhra K, Tokatlian T. Synthetic nanoparticles for vaccines and immunotherapy. Chem Rev (2015) 115(19):11109-46. doi:10.1021/acs.chemrev.5b00109

109. Xu LG, Xiang J, Peng R, Liu Z. Recent advances in the development of nanomaterials for DC-based immunotherapy. Sci Bull (2016) 61(7):514-23. doi:10.1007/s11434-016-1038-6

110. Cambi A, Lidke DS, Arndt-Jovin DJ, Figdor CG, Jovin TM. Ligand-conjugated quantum dots monitor antigen uptake and processing by dendritic cells. Nano Lett (2007) 7(4):970-7. doi:10.1021/nl0700503

111. Lim YT, Noh YW, Han JH, Cai QY, Yoon KH, Chung BH. Biocompatible polymer-nanoparticle-based bimodal imaging contrast agents for the labeling and tracking of dendritic cells. Small (2008) 4(10):1640-5. doi:10.1002/ smll.200800582

112. Reichardt W, Durr C, von Elverfeldt D, Juttner E, Gerlach UV, Yamada M, et al. Impact of mammalian target of rapamycin inhibition on lymphoid homing and tolerogenic function of nanoparticle-labeled dendritic cells following allogeneic hematopoietic cell transplantation. J Immunol (2008) 181(7):4770-9. doi:10.4049/jimmunol.181.7.4770

113. Long CM, van Laarhoven HWM, Bulte JWM, Levitsky HI. Magnetovaccination as a novel method to assess and quantify dendritic cell tumor antigen capture and delivery to lymph nodes. Cancer Res (2009) 69(7):3180-7. doi:10.1158/0008-5472.CAN-08-3691

114. Cruz LJ, Tacken PJ, Bonetto F, Buschow SI, Croes HJ, Wijers M, et al. Multimodal imaging of nanovaccine carriers targeted to human dendritic cells. Mol Pharm (2011) 8(2):520-31. doi:10.1021/mp100356k

115. Xiang J, Xu LG, Gong H, Zhu WW, Wang C, Xu J, et al. Antigen-loaded upconversion nanoparticles for dendritic cell stimulation, tracking, and vaccination in dendritic cell-based immunotherapy. ACS Nano (2015) 9(6):6401-11. doi:10.1021/acsnano.5b02014

116. Park YM, Lee SJ, Kim YS, Lee MH, Cha GS, Jung ID, et al. Nanoparticlebased vaccine delivery for cancer immunotherapy. Immune Netw (2013) 13(5):177-83. doi:10.4110/in.2013.13.5.177

117. Fontana F, Liu D, Hirvonen J, Santos HA. Delivery of therapeutics with nanoparticles: what's new in cancer immunotherapy? Wiley Interdiscip Rev Nanomed Nanobiotechnol (2017) 9(1):e1421. doi:10.1002/wnan.1421
118. Xiang SD, Wilson K, Day S, Fuchsberger M, Plebanski M. Methods of effective conjugation of antigens to nanoparticles as non-inflammatory vaccine carriers. Methods (2013) 60(3):232-41. doi:10.1016/j.ymeth.2013.03.036

119. Nembrini C, Stano A, Dane KY, Ballester M, van der Vlies AJ, Marsland BJ, et al. Nanoparticle conjugation of antigen enhances cytotoxic T-cell responses in pulmonary vaccination. Proc Natl Acad Sci U S A (2011) 108(44):E989-97. doi:10.1073/pnas.1104264108

120. Guo Y, Han W. Cytokine-induced killer (CIK) cells: from basic research to clinical translation. Chin J Cancer (2015) 34(3):99-107. doi:10.1186/ s40880-015-0002-1

121. Lee JH, Lim YS, Yeon JE, Song TJ, Yu SJ, Gwak GY, et al. Adjuvant immunotherapy with autologous cytokine-induced killer cells for hepatocellular carcinoma. Gastroenterology (2015) 148(7):1383-91.e6. doi:10.1053/j. gastro.2015.02.055

122. Weng DS, Zhou J, Zhou QM, Zhao M, Wang QJ, Huang LX, et al. Minimally invasive treatment combined with cytokine-induced killer cells therapy lower the short-term recurrence rates of hepatocellular carcinomas. J Immunother (2008) 31(1):63-71. doi:10.1097/CJI.0b013e31815a121b

123. Hui D, Qiang L, Jian W, Ti Z, Da-Lu K. A randomized, controlled trial of postoperative adjuvant cytokine-induced killer cells immunotherapy after radical resection of hepatocellular carcinoma. Dig Liver Dis (2009) 41(1):36-41. doi:10.1016/j.dld.2008.04.007

124. Takayama T, Sekine T, Makuuchi M, Yamasaki S, Kosuge T, Yamamoto J, et al. Adoptive immunotherapy to lower postsurgical recurrence rates of hepatocellular carcinoma: a randomised trial. Lancet (2000) 356(9232):802-7. doi:10.1016/S0140-6736(00)02654-4

125. Lee JH, Lee JH, Lim YS, Yeon JE, Song TJ, Yu SJ, et al. Adjuvant immunotherapy with autologous cytokine-induced killer cells for hepatocellular carcinoma. Gastroenterology (2015) 148(7):1383-91. doi:10.1053/j. gastro.2015.02.055

126. Wang H, Liu A, Bo W, Feng X, Hu Y, Tian L, et al. Adjuvant immunotherapy with autologous cytokine-induced killer cells for hepatocellular carcinoma patients after curative resection, a systemic review and meta-analysis. Dig Liver Dis (2016) 48(11):1275-82. doi:10.1016/j.dld.2016.07.010

127. Xie F, Zhang X, Li H, Zheng T, Xu F, Shen R, et al. Adoptive immunotherapy in postoperative hepatocellular carcinoma: a systemic review. PLoS One (2012) 7(8):e42879. doi:10.1371/journal.pone.0042879

128. Li X, Dai D, Song X, Liu J, Zhu L, Xu W. A meta-analysis of cytokine-induced killer cells therapy in combination with minimally invasive treatment for hepatocellular carcinoma. Clin Res Hepatol Gastroenterol (2014) 38(5):58391. doi:10.1016/j.clinre.2014.04.010

129. Ma Y, Xu YC, Tang L, Zhang Z, Wang J, Wang HX. Cytokine-induced killer (CIK) cell therapy for patients with hepatocellular carcinoma: efficacy and safety. Exp Hematol Oncol (2012) 1(1):11. doi:10.1186/2162-3619-1-11

130. Li R, Wang C, Liu L, Du C, Cao S, Yu J, et al. Autologous cytokine-induced killer cell immunotherapy in lung cancer: a phase II clinical study. Cancer Immunol Immunother (2012) 61(11):2125-33. doi:10.1007/s00262-012-1260-2

131. Chen Y, Lin WS, Zhu WF, Lin J, Zhou ZF, Huang CZ, et al. Tumor MICA status predicts the efficacy of immunotherapy with cytokine-induced killer cells for patients with gastric cancer. Immunol Res (2016) 64(1):251-9. doi:10.1007/ s12026-015-8743-0

132. Chen Y, Lin J, Guo ZQ, Lin WS, Zhou ZF, Huang CZ, et al. MHC I-related chain a expression in gastric carcinoma and the efficacy of immunotherapy with cytokine-induced killer cells. Am J Cancer Res (2015) 5(10):3221-30.

133. Li X, Dai X, Shi L, Jiang Y, Chen X, Chen L, et al. Phase II/III study of radiofrequency ablation combined with cytokine-induced killer cells treating colorectal liver metastases. Cell Physiol Biochem (2016) 40(1-2):137-45. doi:10.1159/000452531

134. Wang M, Cao JX, Pan JH, Liu YS, Xu BL, Li D, et al. Adoptive immunotherapy of cytokine-induced killer cell therapy in the treatment of non-small cell lung cancer. PLoS One (2014) 9(11):e112662. doi:10.1371/journal. pone. 0112662

135. Jin C, Li J, Wang Y, Chen X, Che Y, Liu X, et al. Impact of cellular immune function on prognosis of lung cancer patients after cytokine-induced killer cell therapy. Asian Pac J Cancer Prev (2014) 15(15):6009-14. doi:10.7314/ APJCP.2014.15.15.6009

136. Zhao M, Li H, Li L, Zhang Y. Effects of a gemcitabine plus platinum regimen combined with a dendritic cell-cytokine induced killer immunotherapy on 
recurrence and survival rate of non-small cell lung cancer patients. Exp Ther Med (2014) 7(5):1403-7. doi:10.3892/etm.2014.1574

137. Zhang J, Zhu L, Du H, He X, Yin Y, Gu Y, et al. Autologous cytokine-induced killer cell therapy in lung cancer patients: a retrospective study. Biomed Pharmacother (2015) 70:248-52. doi:10.1016/j.biopha.2014.12.025

138. Zhang L, Yang X, Sun Z, Li J, Zhu H, Li J, et al. Dendritic cell vaccine and cytokine-induced killer cell therapy for the treatment of advanced non-small cell lung cancer. Oncol Lett (2016) 11(4):2605-10. doi:10.3892/ ol.2016.4273

139. Jia H, Tian Y, Jiang CG, Han W. Evaluation of 29 indicators for the prognosis of advanced non-small cell lung cancer with cytokine-induced killer cell therapy combined with chemotherapy. Exp Ther Med (2016) 11(5):1601-10. doi:10.3892/etm.2016.3102

140. Zhao H, Wang Y, Yu J, Wei F, Cao S, Zhang X, et al. Autologous cytokineinduced killer cells improves overall survival of metastatic colorectal cancer patients: results from a phase II clinical trial. Clin Colorectal Cancer (2016) 15(3):228-35. doi:10.1016/j.clcc.2016.02.005

141. Lin T, Song C, Chuo DY, Zhang H, Zhao J. Clinical effects of autologous dendritic cells combined with cytokine-induced killer cells followed by chemotherapy in treating patients with advanced colorectal cancer: a prospective study. Tumour Biol (2016) 37(4):4367-72. doi:10.1007/s13277-015-3957-2

142. Kong DS, Nam DH, Kang SH, Lee JW, Chang JH, Kim JH, et al. Phase III randomized trial of autologous cytokine-induced killer cell immunotherapy for newly diagnosed glioblastoma in Korea. Oncotarget (2016) 8(4):7003-13. doi:10.18632/oncotarget.12273
143. Li H, Huang L, Liu LB, Wang XM, Zhang Z, Yue DL, et al. Selective effect of cytokine-induced killer cells on survival of patients with early-stage melanoma. Cancer Immunol Immunother (2017) 66(3):299-308. doi:10.1007/ s00262-016-1939-x

144. Dutoit V, Migliorini D, Walker PR, Dietrich PY. Immunotherapy of brain tumors. Prog Tumor Res (2015) 42:11-21. doi:10.1159/000436986

145. Jiang J, Wu C, Lu B. Cytokine-induced killer cells promote antitumor immunity. J Transl Med (2013) 11:83. doi:10.1186/1479-5876-11-83

146. Minn AJ, Wherry EJ. Combination cancer therapies with immune checkpoint blockade: convergence on interferon signaling. Cell (2016) 165(2):272-5. doi:10.1016/j.cell.2016.03.031

147. Priceman SJ, Forman SJ, Brown CE. Smart CARs engineered for cancer immunotherapy. Curr Opin Oncol (2015) 27(6):466-74. doi:10.1097/ CCO.0000000000000232

Conflict of Interest Statement: The authors declare that the research was conducted in the absence of any commercial or financial relationships that could be construed as a potential conflict of interest.

Copyright $\odot 2017$ Gao, Mi, Guo, Xu, Xu, Gou and Jin. This is an open-access article distributed under the terms of the Creative Commons Attribution License (CC BY). The use, distribution or reproduction in other forums is permitted, provided the original author(s) or licensor are credited and that the original publication in this journal is cited, in accordance with accepted academic practice. No use, distribution or reproduction is permitted which does not comply with these terms. 